\title{
Correlation and Path Coefficient Analysis of Morphological Quantitative Characters in Some Ethiopian Specialty Coffee (Coffea arabica L.) Accessions
}

\author{
Meseret Degefa ${ }^{1, *}$, Sentayehu Alamerew ${ }^{2}$, Ali Mohammed², Adeba Gemechu \\ ${ }^{1}$ Awada Agricultural Research Sub- Centre, Yirgalema, Ethiopia \\ ${ }^{2}$ Colleges of Agriculture and Veterinary Medicine (JUCAVM), Jimma University, Jimma, Ethiopia
}

Email address:

meseret.deg2008@gmail.com (M. Degefa)

${ }^{*}$ Corresponding author

To cite this article:

Meseret Degefa, Sentayehu Alamerew, Ali Mohammed, Adeba Gemechu. Correlation and Path Coefficient Analysis of Morphological Quantitative Characters in Some Ethiopian Specialty Coffee (Coffea Arabica L.) Accessions. American Journal of Agriculture and Forestry. Vol. 9, No. 4, 2021, pp. 248-257. doi: 10.11648/j.ajaf.20210904.22

Received: July 24, 2021; Accepted: August 6, 2021; Published: August 18, 2021

\begin{abstract}
Ethiopia is the motherland and center of genetic diversity of Arabica coffee (Coffea arabica L., Rubiaceae). Receiving extra information on genetic variability is a precondition for more enhancement of coffee (Coffea arabica L.). The present study was carried out to study the correlation and path coefficient analysis of 104 entries consisting of 100 accessions from southern parts of Ethiopia and four standard cultivars were evaluated using augmented design. Data on 22 quantitative traits were recorded from five envoy trees per row for each accession. The result revealed that, for nearly all of the traits phenotypic correlation coefficients were lower than genotypic correlation coefficients, indicative of the inherent union among various traits is less influenced by environment. The genotypic path coefficient analysis revealed that leaf area, number of primary branches, number of nodes of primary branches, canopy diameter, bean width, stem diameter, fruit width, fruit thickness, hundred bean weight, bean thickness and average inter node length of primary branches, had positive direct effects on yield per tree, at the same time as the other traits affected yield indirectly, primarily through total plant height, number of secondary branches, height up to first primary branches, fruit length, bean length, average length of primary branches, leaf width and leaf length, show negative direct sound effects on yield per tree.
\end{abstract}

Keywords: Coffea Arabica, Genetic Variability, Correlation, Path Coefficient Analysis, Yield and Yield Components, Germplasm, Quantitative Characters

\section{Introduction}

Coffee is a perennial field crop which belongs to the cultivated in the tropical and subtropical regions genus Coffea in the Rubiacea family, and is mostly [1]. The genus Coffea comprises nearly 124 well recognized species [2] of which only two species, Coffea Arabica Linnaeus (Arabica coffee) and Coffea canephora Pierre (Robusta coffee) are the two commercially key species. Arabica coffee is by far the mainly important commercial species and put in to more than $70 \%$ of world coffee production [3]. Coffea arabica is a selffertile allotetraploid $(2 n=4 x=44)$, as others are diploid $(2 \mathrm{n}=2 \mathrm{x}=22)$ and self-infertile $[4,5]$.

Arabica coffee is the highly preferred non-alcoholic international beverage, and is an extremely vital source of foreign exchange income for many countries. A few estimated that the entire coffee supply chain provides a livelihood for 125 million people worldwide [6] and is the next most exported commodity after oil universally [2]. Ethiopia is the highest producer of coffee in Africa and the fifth major exporter in the world next to Brazil, Vietnam, Colombia and Indonesia, contributing to $4.2 \%$ of the total world coffee production [7]. Ethiopia is not only the foremost producer and exporter of Arabica coffee, but also origin and center of genetic diversity in the southwestern highlands of the country. Besides, despite tremendous coffee genetic resources in the crop species, the country has not yet been fully utilizing its coffee genetic resources as expected in 
terms of improving coffee productivity and detailed information on the extent of association and path coefficient analysis of morphological characters is not yet available.

Correlation coefficient is the measure of the degree of the linear relationship between two variables [8]. Its value ranges between -1 and 1 and the negative one indicate perfect negative linear relationship between the two characters were as positive one indicates perfect positive linear relationship between the characters and zero point out lack of any linear relationship between the two characters. Association of characters among yield, its components, and other economic traits is important for making a selection in a breeding program and associating several desirable traits. It suggests the advantage of a scheme of selection for more than one character at a time [9]. Thus, to help selection in breeding for high yield, it is logical to examine various components and give more interest to those having the greatest influence on yield. The association between two characters that can be directly observed is the correlation of phenotypic values or phenotypic correlations. Phenotypic correlations measure the extent to which the two observed characters are linearly related. It is determined from measurements of the two characters in a number of individuals in the populations. Genetic correlation is the associations of breeding values (i.e additive genetic variance) of the two characters. The genetic reason of correlation are chiefly pleiotropy, a property of a gene whereby it affects two or more characters, so that if the gene is segregating it causes simultaneous variation in the characters it affects. In addition, linkage is also a cause of transient correlation, particularly in a population derived from a cross between divergent strains. Genetic correlation measures the extent to which degree the same genes or closely linked genes cause co-variation (simultaneous variations) in two different characters. Environmental correlations together with non-additive genetic deviations (i.e. dominance and epistasis genetic deviations) are referred to as environmental correlations $[10,11]$. Although estimates of correlation coefficients are helpful in determining the components of a complex trait, such as yield, they do not provide an exact picture of the relative importance or direct and indirect influences of each of the component characters on yield [12]. Path analysis allows a more precise clarification of the pattern of interaction of other known factors. It permits identification of direct and indirect causes of association and measures the relative importance of each character [13]. It is obvious that the yield is the result of yield-correlated characters and some other undefined factors. Therefore, the use of this method requires a cause and effect relation among the variables [14]. Yield in coffee is commercially an imperative trait, which is considered by most, if not all, breeding goals of coffee enhancement. Therefore, it is enviable to know the direct and indirect effect of yield related traits in coffee. These traits could be helpful indicators in breeding programs to select coffee genotype for yield. Keeping this in view, though information is scanty on path coefficient analysis of coffee morphological characters. Hence, inclusive information on the association among various morphological characters has a paramount importance in genetic improvement of coffee yield by shortening the breeding system. Hence, this study was carried out to detect correlation and path coefficient analysis of morphological characters for increased the yield of Ethiopian specialty coffee.

\section{Materials and Methods}

\subsection{Description of the Experimental Area}

The study was conducted at Awada Agricultural Research Sub Center. It is found at $315 \mathrm{~km}$ from Addis Ababa in southern Ethiopia near Yirgalem town. The sub-center is located in the moderate to cool semi-arid mid highland agroecology of southern Ethiopia. Geographically, it is located at $6^{\circ} 3^{\prime} \mathrm{N}$ latitude and $38^{\circ} \mathrm{E}$ longitude at an altitude at an elevation of about 1740 m.a.s.l. The area has a semi-bimodal rainfall distribution characterized by double wet and dry seasons with an average precipitation of $1342 \mathrm{~mm}$ per annum. The average annual minimum and maximum air temperatures are 11 and $28.4^{\circ} \mathrm{C}$, respectively while the annual mean minimum and maximum rainfall are 858.1 and $1676.3 \mathrm{~mm}[15]$.

\subsection{Genotypes}

The study was carried out on the established $100 C$. arabica genotypes together with four standard checks. The coffee genotypes were collected from the potential and representing areas in the southern coffee growing part of Ethiopia. Details of geographical origin of the collected genotypes were given in Table 1 .

\subsection{Treatments and Experimental Design}

Treatments consisted of 100 coffee accessions and four released varieties (75227, 744, 7440 and 1377) were incorporated as standard checks. The experiment was planted using an augmented design, which is used with replicated controls (checks) to assess the performance of non-replicated accession in complete block designs in five blocks in a single row (plot) consisting of ten trees per plot. The plant-to plant spacing used was two meters by two meters, while spacing between blocks were four meters. All the recommended agronomic practices were applied evenly to all the plots [16].

\subsection{Methods of Data Collection}

In the course of this study, data on 22 quantitative characteristics, namely: total plant height $(\mathrm{cm})$, Height up to first primary branch $(\mathrm{cm})$, main stem diameter $(\mathrm{cm})$, canopy diameter (cm), number of primary branches (no), percentage of bearing primary branches (\%), number of secondary branches (no), average length of primary branches $(\mathrm{cm})$, number of nodes of primary branches (no), leaf length $(\mathrm{cm})$, leaf width $(\mathrm{cm})$, leaf area $\left(\mathrm{cm}^{2}\right)$, fruit length $(\mathrm{mm})$, fruit width $(\mathrm{mm})$, fruit thickness $(\mathrm{mm})$, bean length $(\mathrm{mm})$, bean 
width $(\mathrm{mm})$, bean thickness $(\mathrm{mm})$, hundred bean weight $(\mathrm{gm})$, yield per tree $(\mathrm{g})$, coffee berry disease $(\%)$ and rust incidence $(\%)$, were collected from each accession using the standard procedures of [17].

Table 1. Description of the genotypes.

\begin{tabular}{|c|c|c|c|c|}
\hline Genotype & Districts & Specific location & Altitude (m.a.s.l) & Total no collected \\
\hline Aw 05/06, Aw 59/06, Aw 94/06, Aw 111/06 & Bensa & Tibiro & $1750-1800$ & 4 \\
\hline Aw 64/06, Aw 103/06 & Bensa & Silinga & $1740-1770$ & 2 \\
\hline Aw 81/06, Aw 66/06, Aw 12/06, Aw 99/06 & Bensa & ware & $1850-1210$ & 4 \\
\hline Aw $79 / 06$ & Bensa & Hedamo & 1800 & 1 \\
\hline Aw 58/06, Aw 29/06, Aw 107/06 & Bensa & Segera & $1750-1930$ & 3 \\
\hline Aw 97/06, Aw 100/06, Aw 67/06, Aw 108/06, Aw 04/06 & Bensa & Setamo & $1790-2015$ & 5 \\
\hline Aw 71/06, Aw 98/06, Aw 89/06, Aw 78/06, Aw 73/06 & Bensa & Shema lega & $1790-2020$ & 5 \\
\hline Aw 10/06, Aw 62/06, Aw 91/06, Aw 84/06, Aw 28/06, Aw 95/06 & Bensa & Gungvma & $1720-1790$ & 6 \\
\hline Aw 27/06, Aw 68/06, Aw 83/06, Aw 72/06 & Bensa & Hatese & $1750-1810$ & 4 \\
\hline Aw 02/06, Aw 88/06, Aw 90/06 & Bensa & Micharo-2 & $1720-1800$ & 3 \\
\hline Aw 67/06, Aw 112/06 & Bensa & Mulke & $1750-1760$ & 2 \\
\hline Aw 60/06, Aw 61/06, Aw 109/06 & Bensa & Abaye & $1740-1750$ & 3 \\
\hline Aw 08/06, Aw 22/06, Aw 26/06, Aw 74/06, Aw 76/06 & Bensa & Leleno & $1750-1830$ & 5 \\
\hline Aw $14 / 06$ & Bensa & Mike & 1780 & 1 \\
\hline Aw 34/06, Aw 65/06 & Dara & Chire & 1800 & 2 \\
\hline Aw 16/06, Aw 75/06, Aw 80/06 & Dara & Kisho & 1770 & 3 \\
\hline Aw 01/06, Aw 07/06, Aw 41/06, Aw 51/06 & Dara & Wachi cha & 1800 & 4 \\
\hline Aw $24 / 06$ & Dara & Boreta & 1750 & 1 \\
\hline Aw 21/06 & Dara & Doke & 1750 & 1 \\
\hline Aw 23/06 & Dara & Olone & 1750 & 1 \\
\hline Aw 19/06, Aw 57/06, Aw 85/06 & Dara & HalelaDaka & 1750 & 3 \\
\hline Aw 49/06, Aw 54/06, Aw 87/06 & Dara & Buna Tawaba & 1740 & 3 \\
\hline Aw 53/06, Aw 56/06, Aw 63/06, Aw 77/06 & Dara & Loya & 1750 & 4 \\
\hline Aw 11/06, Aw 25/06, Aw 42/06, Aw 55/06 & Dara & Chiro & 1800 & 4 \\
\hline Aw 06/06, Aw 39/06, Aw 52/06, Aw 70/06 & Dara & Shilicho & $180-1810$ & 4 \\
\hline Aw 32/06, Aw 40/06, Aw 43/06 & Dara & Babe Kombolcha & 1830 & 3 \\
\hline Aw 31/06, Aw 38/06, Aw 46/06 & Dara & AlemeKancha & $1750-1800$ & 3 \\
\hline Aw 17/06, Aw 18/06, Aw 45/06, Aw 82/06 & Dara & Bango Markos & $1750-1875$ & 4 \\
\hline Aw 03/06, Aw 09/06 & Dara & Dubancho & $1760-1800$ & 2 \\
\hline $744,7440,75227,1377$ & & & & \\
\hline
\end{tabular}

\subsection{Methods of Data Analysis}

\subsubsection{Correlation Coefficient}

Genotypic and phenotypic correlations among pair of traits were calculated by using the formula given by [18]:

$$
r_{p x y}=\frac{\text { Covpxy }}{\sqrt{\sigma^{2} p x \sigma^{2} p y}}
$$

Where: $\mathrm{rp}=$ phenotypic correlation coefficient; Covpxy= phenotypic covariance between character $\mathrm{x} \& \mathrm{y} ; \sigma^{2} \mathrm{px}=$ phenotypic variance for character $\mathrm{x}$ and $\sigma^{2}$ py= phenotypic variance for character $y$

$$
r_{g x y}=\frac{\operatorname{Covgxy}}{\sqrt{\sigma^{2} g x \sigma^{2} g y}}
$$

Where: $r g=$ genotypic correlation coefficient; Covgxy= genotypic covariance between character $\mathrm{x}$ and $\mathrm{y} ; \sigma^{2} \mathrm{gx}=$ genotypic variance for character $\mathrm{x}$ and $\sigma^{2}$ gy $=$ genotypic variance for character $y$

\subsubsection{Path Coefficient Analysis}

Path coefficient analysis was carried out by using the correlation coefficients to identify the direct and indirect sound effects of the components on yield as shown by [14]. The formula:

$$
r i j=p i j+\sum r i k p k j
$$

where, rij=Mutual association between the independent character (i) and dependent character (j) as measured by the genotypic correlation coefficient, $\mathrm{Pij}=$ Component of direct effects of the independent character (i) and dependent character (j) as measured by the genotypic path coefficient and Srikpkj = Summation of components of indirect effect of a given independent character (i) on the given dependent character (j) via all other independent character (k) The residual effect (h) was estimated by the following formula:$\mathrm{h}=$ where, $\mathrm{R} 2 \mathrm{P}=\mathrm{Pij}=$ Component of direct effects of the independent character (i) and dependent character (j) as measured by the path coefficient. rij = Mutual association between the independent character (i) and dependent 
character $(\mathrm{j})$ as measured by the correlation coefficient.

\section{Results and Discussion}

\subsection{Phenotypic and Genotypic Correlation of Yield with Other Traits}

Genotypic and phenotypic correlation coefficients of 22 quantitative traits were computed and presented in (Tables 2 and 3). The result revealed that, for most of the traits phenotypic correlation coefficients were lower than genotypic correlation coefficients, indicating the inherent association among various traits is less influenced by environment. Accordingly, fruit width, leaf width, leaf area, stem diameter, canopy diameter, bean width and bean thickness, exhibited significant $(\mathrm{P}<0.05)$ and positive phenotypic association with yield per tree, indicating accessions producing wider and thick beans were high yielder.

Alternatively, leaf length, fruit thickness, fruit width, bean length, hundred bean weight, height up to first primary branches, total plant height, number of main stem nodes, percentage of bearing primary branches, number of primary branches, number of secondary branches and coffee berry disease, showed positive and significant $(\mathrm{P}<0.05)$ phenotypic correlations with leaf width, leaf area, stem diameter, canopy diameter, bean width and bean thickness. Hence, indirect selection in favor of these traits can improve yield per tree in coffee. Most of the remaining quantitative morphological traits had positive and non- significant correlation with yield per tree. However, average length of primary branches, coffee berry disease and coffee leaf rust reaction showed a negative and significant correlation with yield. Moreover, total plant height and number of secondary plant showed negative and non-significant phenotypic correlation with yield. In the same way, yield per tree displayed a positive and non-significant genotypic correlation with most of the quantitative traits measured. However, it showed negative and non-significant genotypic correlation with total plant height and number of secondary branches. Most of the traits associations in the current study were also in conformity with the report of earlier researchers [19-24]. In this study yield exhibited a positive and negative phenotypic as well as genotypic linear relationship with most of other studied traits, the reason behind will be, since arabica coffee as perennial crop, its yield is influenced by a variety of factors.

\subsection{Correlation Among Other Quantitative Traits}

\subsubsection{Phenotypic Correlation Coefficients}

Phenotypic correlation coefficients among other pairs of quantitative traits were presented below diagonal (Table 2). Consequently, positive and significant correlation was exhibited between plant height with number of primary branches (0.635), average length of primary branches (0.274), canopy diameter $(0.257)$, height up to first primary branches $(0.254)$, and stem diameter (0.402). Positive and significant correlation was found between stem diameter with number of primary branches (0.46), number of secondary branches $(0.23)$ and canopy diameter $(0.652)$ while it was negative and significant association with average length of primary branches $(-0.20)$ and coffee leaf rust $(-0.189)$.

Similarly, canopy diameter showed positive and significant association with number of primary branches (0.368) and number of secondary branches $(0.414)$, while it was negative and significant association with percentage of bearing primary branches $(-0.247)$. Positive and significant correlation was exhibited between the number of primary branches with a number of secondary branches $(0.219)$ and coffee berry disease (0.195). Number of nodes of a primary branch exhibited a positive and significant correlation with the number of secondary branch $(0.261)$ and coffee berry disease $(0.242)$. Number of secondary branches had a positive and significant association with coffee berry disease (0.385).

Fruit and bean characters, fruit length showed a positive and significant correlation with fruit width $(0.487)$, fruit thickness $(0.346)$, bean width $(0.332)$, bean length $(0.632)$, hundred bean weight $(0.530)$, height up first primary $(0.183)$, leaf width (0.241) and leaf area (0.269). Fruit width showed a positive and significant correlation with fruit thickness (0.697), bean width (0.364), bean length $(0.348)$, bean thickness (0.314), hundred bean weight $(0.463)$ and bean length (0.37). Likewise, Fruit thickness showed a positive and significant correlation with bean width $(0.335)$, bean thickness $(0.217)$, hundred bean weight $(0.385)$, bean length $(0.291)$ and leaf length (0.198) and canopy diameter (0.232) while it was negative and significant association with number of primary branches $(-0.222)$ and number of secondary branches (-0.219). Bean length showed a positive and significant association with hundred bean weight $(0.747)$, bean thickness $(0.269)$, bean width (0.529) and length of primary branch $(0.222)$. Bean width showed positive and significant correlation with bean thickness $(0.505)$ and hundred bean weight $(0.740)$, percent of bearing primaries (0.229); whereas, bean thickness showed negative and significant association with canopy diameter (0.192). Hundred bean weight showed a positive and significant correlation with percent of bearing primaries $(0.215)$ while it was negative and significant association with the number of primary branches $(-0.183)$ and number of secondary branches $(-0.198)$ and canopy diameter $(-0.270)$. Most of the correlations of these paired quantitative traits were in agreement with the previous finding of phenotypic traits association $[21,22,24]$.

Leaf characters, leaf length showed a positive and significant association with hundred bean weight $(0.244)$, bean thickness (0.239), bean width (0.259), bean length (0.308), leaf area (0.646) and percent of bearing primaries $(0.234)$ while it was negative and significant association with number of secondary branches $(-0.250)$. leaf width showed a positive and significant association with leaf area (0.858), number of secondary branches $(0.244)$, canopy diameter $(0.407)$, stem diameter $(0.279)$ and coffee berry disease $(0.187)$ while it was negative and significant association with percent of bearing primaries $(-0.353)$. Finally leaf area showed a positive and 
significant association with bean length (0. 248), canopy diameter (0.282) and stem diameter (0.250).

Coffee berry disease illustrated negative and no significant association with most of the traits considered. Coffee leaf rust severity exhibited positive and significant associations with coffee berry disease severity $(0.526)$ which means the presence of one disease will aggravate the other. The present finding is in agreement with [20] who noted coffee berry disease exhibited a non-significant association with most of the quantitative traits studied. [22] also suggested that coffee berry disease exhibited non- significant association with most of the traits apart from the primary branches and the number of main stem node which had a positive and significant correlation with coffee berry disease.

Table 2. Phenotypic correlation coefficients among 22 traits of 104 coffee germplasm accessions tested.

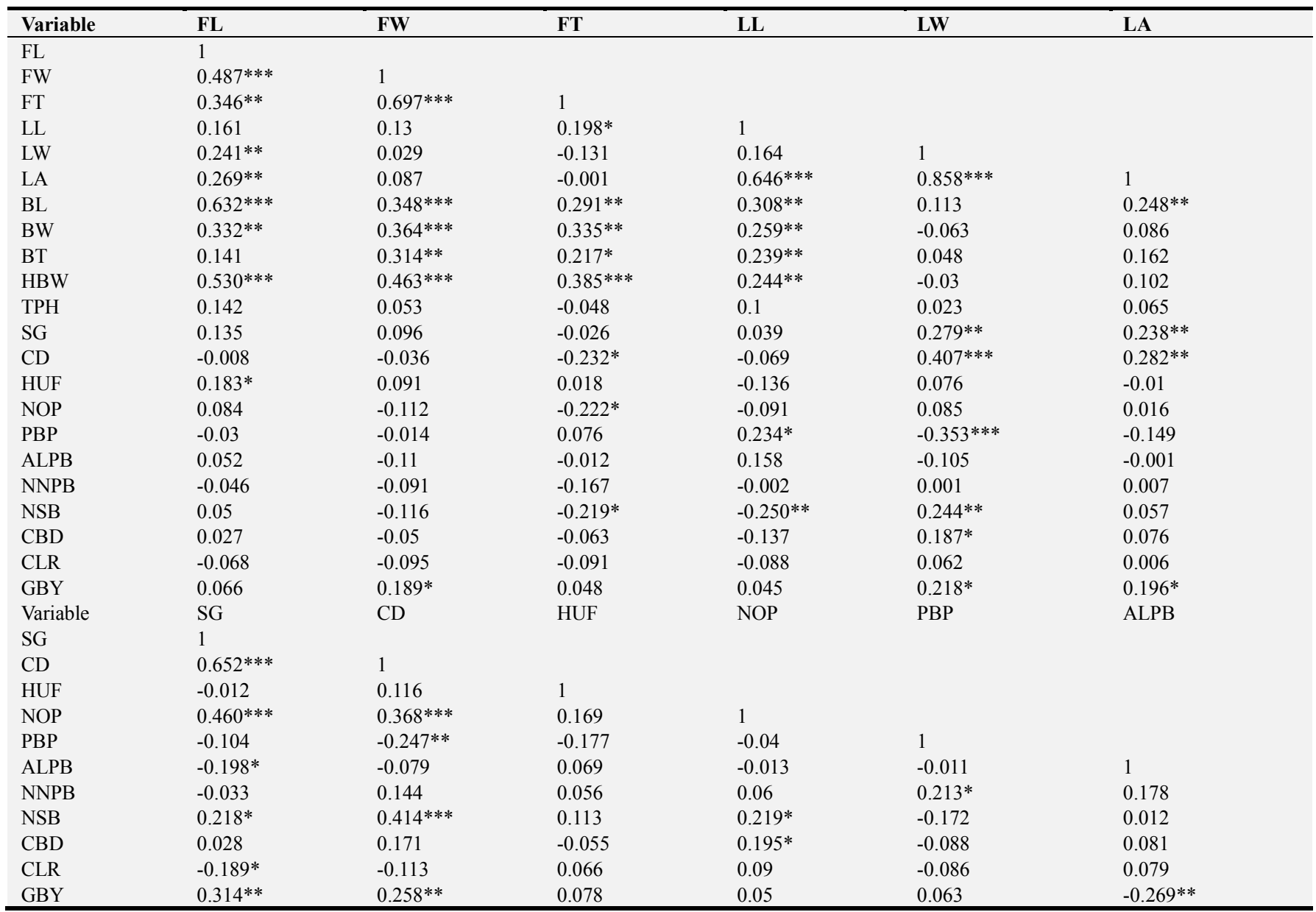

Table 2. Continued.

\begin{tabular}{|c|c|c|c|c|c|}
\hline Variable & BL & BW & BT & HBW & ТPH \\
\hline \multicolumn{6}{|l|}{ FL } \\
\hline \multicolumn{6}{|l|}{ FW } \\
\hline \multicolumn{6}{|l|}{ FT } \\
\hline \multicolumn{6}{|l|}{ LL } \\
\hline \multicolumn{6}{|l|}{ LW } \\
\hline \multicolumn{6}{|l|}{ LA } \\
\hline BL & 1 & & & & \\
\hline BT & $0.269 * *$ & $0.505 * * *$ & 1 & & \\
\hline HBW & $0.747 * * *$ & $0.740 * * *$ & $0.450 * * *$ & 1 & \\
\hline TPH & 0.078 & -0.074 & -0.003 & -0.061 & 1 \\
\hline SG & -0.045 & -0.022 & 0.01 & -0.109 & $0.402 * * *$ \\
\hline $\mathrm{CD}$ & -0.149 & $-0.194 *$ & -0.092 & $-0.270 * *$ & $0.257 * *$ \\
\hline HUF & 0.078 & -0.083 & -0.038 & 0.046 & $0.254 * *$ \\
\hline NOP & -0.053 & -0.14 & -0.042 & $-0.183^{*}$ & $0.635 * * *$ \\
\hline ALPB & $0.222 *$ & -0.024 & $-0.264 * *$ & 0.088 & $0.274 * *$ \\
\hline NNPB & -0.054 & -0.007 & -0.172 & -0.147 & 0.04 \\
\hline
\end{tabular}




\begin{tabular}{|c|c|c|c|c|c|}
\hline Variable & BL & BW & BT & HBW & TPH \\
\hline NSB & -0.072 & -0.153 & $-0.296^{* *}$ & $-0.198^{*}$ & 0.084 \\
\hline CBD & -0.006 & -0.168 & $-0.227^{*}$ & -0.09 & 0.16 \\
\hline CLR & -0.079 & -0.11 & 0.03 & -0.062 & 0.143 \\
\hline GBY & 0.036 & $0.264 * *$ & $0.314 * *$ & 0.092 & -0.003 \\
\hline Variable & NNPB & NSB & CBD & CLR & GBY \\
\hline \multicolumn{6}{|l|}{ SG } \\
\hline \multicolumn{6}{|l|}{$\mathrm{CD}$} \\
\hline \multicolumn{6}{|l|}{ HUF } \\
\hline \multicolumn{6}{|l|}{ NOP } \\
\hline \multicolumn{6}{|l|}{ PBP } \\
\hline \multicolumn{6}{|l|}{ ALPB } \\
\hline NNPB & 1 & & & & \\
\hline NSB & $0.261 * *$ & 1 & & & \\
\hline CBD & $0.242 * *$ & $0.38506^{* * *}$ & 1 & & \\
\hline CLR & 0.095 & 0.0605 & $0.526 * * *$ & 1 & \\
\hline GBY & 0.073 & -0.057 & $-0.401 * * *$ & $-0.341 * *$ & 1 \\
\hline
\end{tabular}

\subsubsection{Genotypic Correlation Coefficients}

Estimates of genotypic correlation coefficients among the pairs of quantitative traits were also presented above the diagonal in (Table 3). The shoot characteristics had either positive or negative genotypic correlation with each other or other characteristics. In view of that, total plant height showed positive and significant correlation with height up to first primary branches $(0.261)$, number of primary branches $(0.643)$, stem diameter $(0.417)$, canopy diameter $(0.262)$ and average length of primary branches $(0.265)$. Likewise, stem diameter exhibited positive and significant correlation with number of primary branches $(0.464)$, leaf width $(0.28)$, leaf area $(0.24)$, secondary branches $(0.227)$, canopy diameter (0.654) and average length of primary branches (0.198). Significant and positive association of plant height and stem diameter with other quantitative traits was partially in agreement with the report of previous authors [19,21, 22].

Accordingly, positive and significant correlation was observed between canopy diameter with a number of secondary branches $(0.418)$ and number of primary branches $(0.370)$. The association between number of primary branches and number of secondary branches $(0.221)$ was positive and significant. Equally, number of nodes on the primary branches had a positive and significant association with the number of secondary branches $(0.254)$ and coffee berry disease (0.248). Similarly, number of secondary branches had a positive and significant association with coffee berry disease $(0.391)$.

In the same manner, fruit characters showed positive and negative significant correlation with each other or other characteristics. Hence, fruit width exhibited a positive and significant association with fruit thickness $(0.703)$, bean width (0.362), bean thickness (0.314), bean length (0.353) and hundred bean weight (0.461). Positive and significant association were observed between fruit thickness with bean width (0.335), bean thickness (0.216), bean length (0.307), hundred bean weight (0.384), leaf length (0.193), However, it had negative and significant association with number of primary branch $(-0.224)$, number of secondary branch $(-0.220)$ and canopy diameters $(-0.228)$. Positive and significant association were observed between fruit length with fruit width
(0.480), fruit thickness (0.348), bean length (0.645), fruit width (0.333), hundred bean weight $(0.527)$, leaf area $(0.279)$, leaf width $(0.247)$ and height up to first primary branches $(0.195)$.

Bean characters in addition showed relations with the rest of the characteristics considered. So, Positive and significant association was observed between bean length with hundred bean weight $(0.764)$, bean width $(0.541)$, bean thickness $(0.270)$ and average length of primary branches (0.219). In the same way, bean width showed a positive and significant relationship with the percentage of bearing primary branches (0.232), bean thickness $(0.513)$ and hundred bean weight (0.745). Bean thickness also showed a positive and significant association with leaf length $(0.23)$ and hundred bean weight $(0.452)$ on the other hand, it had negative and significant association with number of secondary branch ($0.305)$, coffee berry disease $(-0.229)$ and average length of primary branches $(-0.268)$. The association among a hundred bean weight with percentage of bearing primary branches (0.208) was positive and significant but, it had a negative and significant association with the number of secondary branch $(-0.203)$ and canopy diameters $(-0.262)$. Most of the traits associations in the current study were also in conformity with the report of earlier researchers [19-23].

Leaf length showed positive and significant association with leaf area (0.647), bean length $(0.319)$, bean width (0.262), number of primary branches $(0.248)$, number of secondary branches (0.249), bean thickness (0.240) and hundred bean weight $(0.249)$. Leaf width showed a positive and significant association with leaf area (0.859), canopy diameters $(0.411)$, stem diameter $(0.286)$ and number of secondary branches $(0.237)$. Leaf area a showed positive and significant association with bean length (0.251), canopy diameters (0.287) and stem diameter (0.245).

On the other hand, disease reaction traits also revealed positive and negative significant associations with the other traits considered such as, coffee berry disease severity showed negative and significant correlation with bean thickness $(-0.229)$, while it had negative and non-significant association with the rest of fruit and bean quantitative traits. Even though, CBD mainly attacks fruit and berries, interestingly the disease showed a negative association with fruit and bean quantitative traits, which has an important 
implication in the improvement of these traits during disease resistant coffee cultivar development. The association of coffee leaf rust reaction was also negative with most of the traits. Furthermore, the association between coffee berry disease and coffee leaf rust (0.531) was positive and significant; suggesting simultaneous evaluations of coffee accessions for these closely associated important traits in future disease resistant cultivar development. This result is in agreement with [22].

Normally, the association could be either genetic or environment or else the contribution of both factors.
Therefore, positive correlation among paired traits might allow improving both traits simultaneously, whereas a negative correlation, selection for improving one trait will likely cause decreases the other trait. Positive and significant association of traits due to the effect of genes can be the existence of strong coupling linkage between genes or the traits might be the result of pleiotropic genes that could control the traits in the same direction, while the negative correlation might be because of different genes or pleiotropic genes that have dominance on the traits which would control in different direction.

Table 3. Genotypic correlation coefficients among 22 traits of 104 coffee germplasm accessions tested.

\begin{tabular}{|c|c|c|c|c|c|c|}
\hline Variable & FL & FW & FT & LL & LW & LA \\
\hline FL & 1 & $0.480 * * *$ & $0.340 * *$ & 0.172 & $0.247 *$ & $0.279 *$ \\
\hline FW & & 1 & $0.703 * * *$ & 0.138 & 0.026 & 0.089 \\
\hline FT & & & 1 & $0.193 *$ & -0.135 & -0.007 \\
\hline LL & & & & 1 & 0.167 & $0.647 * * *$ \\
\hline LW & & & & & 1 & $0.859 * * *$ \\
\hline LA & & & & & & 1 \\
\hline \multicolumn{7}{|l|}{ BL } \\
\hline \multicolumn{7}{|l|}{ BW } \\
\hline \multicolumn{7}{|l|}{ BT } \\
\hline \multicolumn{7}{|l|}{ HBW } \\
\hline \multicolumn{7}{|l|}{ ТPH } \\
\hline Variable & SG & CD & HUF & NOP & PBP & ALPB \\
\hline FL & 0.136 & 0.005 & $0.195^{*}$ & 0.092 & -0.033 & 0.045 \\
\hline FW & 0.097 & -0.031 & 0.095 & -0.111 & -0.02 & -0.117 \\
\hline FT & -0.027 & $-0.228^{*}$ & 0.017 & $-0.224^{*}$ & 0.074 & -0.016 \\
\hline LL & 0.043 & -0.066 & -0.145 & -0.099 & $0.248 *$ & 0.162 \\
\hline LW & $0.286^{* *}$ & $0.411 * * *$ & 0.077 & 0.085 & $-0.352 * *$ & -0.117 \\
\hline LA & $0.245^{*}$ & $0.287 * *$ & -0.013 & 0.012 & -0.142 & -0.009 \\
\hline BL & -0.036 & -0.142 & 0.083 & -0.052 & 0.156 & $0.219^{*}$ \\
\hline BW & -0.0168 & -0.19 & -0.088 & -0.142 & $0.232 *$ & -0.029 \\
\hline BT & 0.013 & -0.087 & -0.032 & -0.038 & 0.175 & $-0.268 * *$ \\
\hline HBW & -0.111 & $-0.266^{* *}$ & 0.05 & -0.178 & $0.208^{*}$ & 0.092 \\
\hline ТРН & $0.417 * * *$ & $0.262 * *$ & $0.261 * *$ & $0.643 * *$ & 0.06 & $0.265^{* *}$ \\
\hline SG & 1 & $0.654 * * *$ & -0.011 & $0.464 * * *$ & -0.107 & $-0.198^{*}$ \\
\hline $\mathrm{CD}$ & & 1 & 0.118 & $0.370 * *$ & $-0.252 * *$ & -0.081 \\
\hline HUF & & & 1 & 0.162 & -0.175 & 0.06 \\
\hline NOP & & & & 1 & -0.028 & -0.026 \\
\hline PBP & & & & & 1 & 0.006 \\
\hline ALPB & & & & & & 1 \\
\hline \multicolumn{7}{|l|}{ NNPB } \\
\hline \multicolumn{7}{|l|}{ NSB } \\
\hline \multicolumn{7}{|l|}{ CBD } \\
\hline \multicolumn{7}{|l|}{ CLR } \\
\hline GBY & & & & & & \\
\hline
\end{tabular}

Table 3. Continued.

\begin{tabular}{|c|c|c|c|c|c|}
\hline Variable & BL & BW & BT & HBW & ТРН \\
\hline FL & $0.645 * * *$ & $0.333 * *$ & 0.137 & $0.527 * * *$ & 0.15 \\
\hline FW & $0.355 * *$ & $0.362 * *$ & $0.314 * *$ & $0.461 * * *$ & 0.06 \\
\hline FT & $0.307 * *$ & $0.335 * *$ & $0.216^{*}$ & $0.384 * * *$ & -0.034 \\
\hline LL & $0.319 * *$ & $0.262 * *$ & $0.240 *$ & $0.249 *$ & 0.106 \\
\hline LW & 0.111 & -0.066 & 0.046 & -0.025 & 0.012 \\
\hline LA & $0.251 *$ & 0.086 & 0.161 & 0.108 & 0.059 \\
\hline BL & 1 & $0.541 * * *$ & $0.270 * *$ & $0.764 * * *$ & 0.055 \\
\hline BW & & 1 & $0.513 * * *$ & $0.745 * * *$ & -0.0703 \\
\hline BT & & & 1 & $0.452 * * *$ & -0.006 \\
\hline HBW & & & & 1 & -0.051 \\
\hline TPH & & & & & 1 \\
\hline Variable & NNPB & NSB & CBD & CLR & GBY \\
\hline
\end{tabular}




\begin{tabular}{llllll}
\hline Variable & BL & BW & BT & HBW & TPH \\
\hline FL & -0.045 & 0.051 & 0.027 & -0.075 & 0.062 \\
FW & -0.1002 & -0.1273 & -0.05 & -0.099 & 0.189 \\
FT & -0.1611 & $-0.220^{*}$ & -0.064 & -0.0831 & 0.05 \\
LL & 0.014 & $-0.249^{*}$ & -0.139 & -0.078 & 0.054 \\
LW & 0.009 & $0.237^{*}$ & 0.19 & 0.071 & $0.219^{*}$ \\
LA & 0.021 & 0.052 & 0.078 & 0.018 & $0.201^{*}$ \\
BL & -0.054 & -0.076 & -0.006 & -0.096 & 0.038 \\
BW & -0.009 & -0.164 & -0.168 & $0.265^{* *}$ \\
BT & -0.175 & $-0.305^{* *}$ & $-0.229^{*}$ & 0.112 & $0.326^{* *}$ \\
HBW & -0.153 & $-0.203^{*}$ & -0.091 & -0.066 & 0.097 \\
TPH & 0.04 & 0.08 & 0.164 & 0.136 & -0.004 \\
SG & -0.032 & $0.227^{*}$ & 0.027 & -0.188 & $0.317^{* *}$ \\
CD & 0.146 & $0.418^{* * *}$ & 0.172 & -0.112 & $0.261^{* *}$ \\
HUF & 0.051 & 0.114 & -0.055 & 0.066 & 0.08 \\
NOP & 0.056 & $0.221^{*}$ & $0.196^{*}$ & 0.09 & 0.051 \\
PBP & $0.224 *$ & -0.174 & -0.09 & -0.088 & 0.06 \\
ALPB & -0.0002 & 0.083 & 0.07 & $-0.276^{* *}$ \\
NNPB & 0.173 & 1 & $0.248^{*}$ & 0.078 \\
NSB & & $0.391^{* * *}$ & 0.059 & -0.061 \\
CBD & & 1 & $0.531^{* * *}$ & $-0.402^{* * *}$ \\
CLR & & & 1 & $-0.348^{* *}$ \\
GBY & & & & 1 \\
\hline
\end{tabular}

\subsection{Path Coefficient Analysis}

Although estimates of correlation coefficients are helpful in determining the components of a complex trait, such as yield, they do not provide an exact picture of the relative importance or direct and indirect influences of each of the component traits on yield 12]. Path analysis permits identification of direct and indirect causes of association and measures the relative importance of each character [13]. In the current research, path-coefficient analysis was carried out at the genotypic level using coffee yield per tree as dependent variable and other traits as independent variables which is presented in (Table 4).

Genotypic path coefficient analysis revealed that leaf area (1.242) observed the maximum positive direct effect on yield per tree. Furthermore, number of primary branches $(0.650)$, percentage of bearing primary branches $(0.215)$, number of nodes of primary branches $(0.195)$, canopy diameter $(0.189)$, bean width (0.153), stem diameter (0.132), fruit width $(0.083)$, fruit thickness $(0.076)$, hundred bean weight $(0.051)$ and bean thickness (0.042), also had low magnitude and positive direct effects toward yield per tree. Conversely, total plant height (-0.004), number of secondary branches ($0.005)$, height up to first primary branches $(-0.035)$, fruit length $(-0.120)$, bean length $(-0.040)$, coffee leaf rust severity $(-0.086)$, average length of primary branches $(-0.128)$, leaf width $(-0.658)$, and coffee berry disease $(-0.176)$ and leaf length (-0.792), exhibited negative direct effects on yield per tree. Similarly, [20] reported that the average length of primary branches and leaf width showed a negative direct effect on yield. The current finding was also consistent with [22] who found out the number of nodes of primary branches, average inter-node length of primary branches, number of primary branches, fruit thickness, canopy diameter and stem diameter showed a positive direct effect on yield per plant. The present result was also consistent with [24].

The positive direct effect of fruit thickness, leaf area, percentage of bearing primary branches, number of primary branches and number of nodes on primary branches on yield had path coefficient values larger than their correlation values. Fruit width, bean thickness, bean width, hundred bean weight, stem diameter and canopy diameter were positively correlated with yield while the magnitude of the direct effect is by far less than that of the correlation coefficient, implying the importance of other traits via which these traits contributed to yield per tree. The direct effect of leaf length, leaf width, bean length, fruit length nodes and average length of primary branches on yield was negative, while these traits showed positive and almost negligible genotypic correlation coefficients with yield per tree, in which their indirect effects was via other traits. This in turn, implies that the other traits through which it influenced the indirect effect need to be considered for selection. On the other hand, total plant height, number of secondary branches, coffee berry disease and CLR severity showed negative direct effect and negative correlation coefficients with yield per tree, which implies consideration of these traits like short plant height, minimum number of secondary branch and low level CLR severity would be effective in breeding work. Compare with this result, length of primary branches and coffee berry disease had negative direct effect and negative correlation coefficients with yield per tree [22].

The residual effect in path analysis determines how best the component (independent) variables account for the variability of the dependent variable, yield per plant [18]. Finally, the residual effect of the present study was $(0.700)$, clarified that the variability explained by the component factors toward yield per tree was low. Therefore the remaining unexplained variability will be either due to non-studied traits or the influence of environment on the traits was high. 
Table 4. Estimate of direct (bold diagonal) and indirect effects (off diagonal) at genotypic level of 21 traits on yield in 104 coffee germplasm accessions.

\begin{tabular}{llllllllllll}
\hline Characters & FL & FW & FT & LL & LW & LA & BL & BW & BT & HBW & TPH \\
\hline FL & -0.12 & 0.055 & 0.006 & -0.252 & -0.417 & 0.716 & -0.0191 & 0.0678 & 0.0195 & -0.0185 & 0.0064 \\
FW & -0.053 & 0.083 & 0.053 & -0.101 & -0.017 & 0.104 & -0.015 & 0.055 & 0.013 & 0.024 & 0.000 \\
FT & -0.037 & 0.057 & 0.076 & -0.15 & 0.09 & -0.011 & -0.012 & 0.05 & 0.008 & 0.02 & 0.000 \\
LL & -0.019 & 0.011 & 0.014 & -0.792 & -0.111 & 0.805 & -0.013 & 0.039 & 0.01 & 0.012 & 0.000 \\
LW & -0.027 & 0.002 & -0.01 & -0.134 & -0.658 & 1.068 & -0.005 & -0.011 & 0.002 & -0.002 & 0.000 \\
LA & -0.031 & 0.007 & -0.001 & -0.513 & -0.566 & 1.242 & -0.01 & 0.012 & 0.007 & 0.005 & 0.000 \\
BL & -0.071 & 0.03 & 0.024 & -0.252 & -0.075 & 0.314 & -0.04 & 0.084 & 0.012 & 0.039 & 0.000 \\
BW & -0.037 & 0.03 & 0.025 & -0.202 & 0.048 & 0.095 & -0.022 & 0.153 & 0.022 & 0.038 & 0.000 \\
BT & -0.015 & 0.025 & 0.015 & -0.181 & -0.032 & 0.195 & -0.011 & 0.078 & 0.042 & 0.023 & 0.000 \\
HBW & -0.058 & 0.039 & 0.029 & -0.192 & 0.022 & 0.122 & -0.031 & 0.114 & 0.019 & 0.051 & 0.000 \\
TPH & -0.017 & 0.005 & -0.004 & -0.078 & -0.014 & 0.079 & -0.003 & -0.012 & 0.000 & -0.003 & -0.004 \\
SD & -0.015 & 0.008 & -0.002 & -0.033 & -0.186 & 0.301 & 0.001 & -0.003 & 0.000 & -0.006 & -0.002 \\
CD & -0.001 & -0.002 & -0.017 & 0.048 & -0.27 & 0.359 & 0.006 & -0.029 & -0.004 & -0.014 & -0.001 \\
HUP & -0.022 & 0.008 & 0.001 & 0.123 & -0.045 & -0.031 & -0.003 & -0.017 & -0.002 & 0.002 & -0.001 \\
NPB & -0.011 & -0.009 & -0.017 & 0.08 & -0.056 & 0.014 & 0.002 & -0.023 & -0.001 & -0.01 & -0.002 \\
PBP & 0.004 & -0.002 & 0.005 & -0.191 & 0.236 & -0.187 & -0.006 & 0.035 & 0.007 & 0.011 & 0.000 \\
ALPB & -0.005 & -0.009 & 0.000 & -0.138 & 0.074 & 0.002 & -0.009 & -0.004 & -0.011 & 0.004 & -0.001 \\
NNPB & 0.005 & -0.007 & -0.012 & -0.011 & -0.002 & 0.02 & 0.002 & 0.001 & -0.007 & -0.007 & 0.000 \\
NSB & -0.006 & -0.009 & -0.016 & 0.191 & -0.16 & 0.074 & 0.003 & -0.024 & -0.012 & -0.011 & 0.000 \\
CBD & -0.003 & -0.003 & -0.004 & 0.112 & -0.137 & 0.113 & 0 & -0.026 & -0.01 & -0.004 & -0.001 \\
CLR & 0.008 & -0.007 & -0.006 & 0.045 & -0.052 & 0.043 & 0.003 & -0.013 & 0.002 & -0.002 & -0.001 \\
\hline
\end{tabular}

\begin{tabular}{lllllllllll}
\hline Characters & SD & CD & HUP & NPB & PBP & ALPB & NNPB & NSB & CBD & CLR \\
\hline FL & 0.0155 & 0.00052 & 0.0086 & 0.0022 & -0.0028 & -0.0051 & -0.008 & -0.0013 & -0.011 & 0.01035 \\
FW & 0.012 & -0.005 & -0.003 & -0.068 & -0.005 & 0.013 & -0.016 & 0.001 & 0.000 & 0.007 \\
FT & -0.004 & -0.043 & 0.000 & -0.147 & 0.015 & 0.000 & -0.03 & 0.001 & 0.000 & 0.007 \\
LL & 0.005 & -0.012 & 0.005 & -0.066 & 0.052 & -0.022 & 0.003 & 0.001 & 0.000 & 0.005 \\
LW & 0.037 & 0.078 & -0.002 & 0.055 & -0.077 & 0.014 & 0.001 & -0.001 & 0.000 & -0.007 \\
LA & 0.032 & 0.055 & 0.001 & 0.007 & -0.032 & 0.000 & 0.003 & 0.000 & 0.000 & -0.003 \\
BL & -0.005 & -0.027 & -0.003 & -0.036 & 0.033 & -0.027 & -0.011 & 0.000 & 0.000 & 0.007 \\
BW & -0.003 & -0.036 & 0.004 & -0.098 & 0.049 & 0.003 & 0.002 & 0.001 & 0.000 & 0.007 \\
BT & 0.001 & -0.016 & 0.001 & -0.023 & 0.037 & 0.032 & -0.031 & 0.001 & -0.001 & -0.005 \\
HBW & -0.015 & -0.051 & -0.001 & -0.125 & 0.046 & -0.011 & -0.028 & 0.001 & 0.000 & 0.004 \\
TPH & 0.054 & 0.05 & -0.009 & 0.422 & 0.011 & -0.036 & 0.009 & 0.000 & 0.000 & -0.013 \\
SD & 0.132 & 0.124 & 0.000 & 0.305 & -0.023 & 0.025 & -0.006 & -0.001 & 0.000 & 0.014 \\
CD & 0.086 & 0.189 & -0.004 & 0.243 & -0.054 & 0.011 & 0.027 & -0.002 & 0.001 & 0.008 \\
HUP & -0.002 & 0.023 & -0.035 & 0.096 & -0.038 & -0.008 & 0.014 & -0.001 & 0.000 & -0.005 \\
NPB & 0.062 & 0.071 & -0.005 & 0.65 & -0.006 & 0.004 & 0.012 & -0.001 & 0.000 & -0.009 \\
PBP & -0.014 & -0.048 & 0.006 & -0.017 & 0.215 & 0.000 & 0.045 & 0.001 & 0.000 & 0.006 \\
ALPB & -0.026 & -0.016 & -0.002 & -0.018 & 0.001 & -0.128 & 0.03 & 0.000 & 0.000 & -0.006 \\
NNPB & -0.004 & 0.026 & -0.002 & 0.042 & 0.05 & -0.02 & 0.195 & -0.001 & 0.000 & -0.007 \\
NSB & 0.03 & 0.079 & -0.004 & 0.145 & -0.038 & 0.002 & 0.047 & -0.005 & 0.002 & -0.005 \\
CBD & 0.007 & 0.04 & 0.001 & 0.14 & -0.02 & -0.012 & 0.05 & -0.002 & -0.176 & -0.044 \\
CLR & -0.021 & -0.017 & -0.002 & 0.068 & -0.016 & -0.009 & 0.017 & 0.000 & 0.000 & -0.086 \\
\hline
\end{tabular}

Residual effects $(U)=0.700$; HUP $=$ height up to first primary branches, $\mathrm{TPH}=$ total plant height, $\mathrm{SD}=$ stem diameter, $\mathrm{CD}=$ canopy diameter, $\mathrm{NPB}=$ number of primary branches, $\mathrm{NSB}=$ number of secondary branches, $\mathrm{PBP}=$ percentage of bearing primary branches, $\mathrm{NNPB}=$ number of nodes of primary branches, $\mathrm{ALPB}=$ average length of primary branches, $\mathrm{LL}=$ leaf length, $\mathrm{LW}=$ leaf width, $\mathrm{LA}=$ leaf area, $\mathrm{FL}=$ fruit length, $\mathrm{FW}=$ fruit width, $\mathrm{FT}=$ fruit thickness, $\mathrm{BL}=$ bean length, $\mathrm{BW}=$ bean width, $\mathrm{BT}=$ bean thickness, $\mathrm{HBW}=$ hundred bean weight, $\mathrm{CBD}=$ coffee berry disease, $\mathrm{CLR}=$ coffee leaf rust

\section{Conclusion}

Traits of friendship showed that there is a positive association among most of the traits both of phenotypic and genotypic levels. In addition, most of the traits of coffee had positive correlations amongst each other. This will assist in the combined improvement of these characters by selecting only for greatly heritable characters. Therefore, this is also a valuable chance for coffee breeders to select important characters with less environmentally encourage errors. The genotypic path coefficient analysis revealed that leaf area, number of primary branches, percentage of bearing primary branches, number of nodes of primary branches, canopy diameter, bean width, stem diameter, fruit width, fruit thickness, hundred bean weight, bean thickness and coffee beery disease, also had positive direct effects on yield per tree, while the other traits affected yield indirectly, mainly through total plant height, number of secondary branches, height up to first primary branches, bean length, coffee leaf 
rust severity, average length of primary branches, fruit length, leaf width and leaf length, shows negative direct effects on yield per tree. As a result, these traits could be invoked as a reliable marker in indirect selection for higher yield. To sum up, traits showed that there is a strong association among morphological coffee attributes both of phenotypic and genotypic levels. Furthermore, in order to confirm the present encouraging result, the current findings must be further studied with additional accessions with other traits of interest should be studied over a year.

\section{References}

[1] Berthaud J, Charrier A (1988). Genetic resources of Coffea. In: Clarke R J, Macrae R (eds), Coffee: Agronomy, vol. IV, pp. 1-42. Elsevier Applied Science, London.

[2] Davis AP, Gole TW, and Baena S, Moat J (2012). The impact of climate change on natural populations of Arabica coffee: Predicting future trends and identifying priorities. PLoS ONE 7 (11): e47981.

[3] Gray Q, Tefera A, Tefera T (2013). Coffee Annual Report. GAIN Report No. ET 1302. Coffee Exporter http://www.adulinacoffee.org/coffeeceremony.html.

[4] AnthonyF C, Combes C, AstorgaB, Bertrand G, Graziosi P, Lashermes P (2002). The origin of cultivated Coffea arabica L. varieties revealed by AFLP and SSR markers. Theoretical and Applied Genetics 104: 894-900.

[5] Labouisse JP, Bellachew B, Kotecha S, Bertrand B (2008). Current status of coffee (Coffea Arabica L.) genetic resources in Ethiopia: Implications for conservation. Genetic Resources and Crop Evolution 55: 1079-1093.

[6] BunnCH (2015). Modeling the climate change impacts on global coffee production. Dissertation for the completion of the academic degree Doctor rerum agriculturarum submitted to the faculty of Life Sciences at Humboldt-Universität $\mathrm{zu}$ Berlin. P. 196.

[7] ICO (International Coffee Organization) (2016). $\mathrm{http} / / \mathrm{www} . \mathrm{ico} / \mathrm{org} /$ trade_statistic.asp.

[8] Gomez KA and Gomez AA (1984). Statistical procedure for Agricultural Research (2nd) John Wiley and Sons, New York.

[9] Simmonds, N. W. (1986). Princples of Crop Improvement. Long Man, Singapore. p. 495.

[10] Falconer, D., and F. Mackay, 1996. Introduction to Quantitative Genetics. Longman, New York. 464 p.

[11] Sharma, J. R. (1998). Statistical and biometrical techniques in plant breeding. New Age International (P) Limitted Publishers, New Delhi, 432 p.

[12] Bhatt, G. M (1973). Significance of path coefficient analysis in determining the nature of character association. Euphytica 22: $338-343$.
[13] Ariyo, O. J., M. E. Akeriova and C. A. Fatokun (1987). Plant character correlation and path analysis of pod yield in Okra (Abelmoschusesculentus). Euphytica 36: 677-68.

[14] Dewey, D. R. and K. H. Lu (1959). Acorrelation and path coefficient analysis of components of crested wheat grass seed production. Agronomy Journal, 51: 515-518.

[15] Mesfin K, Bayetta B (2008). Phenotypic Diversity in the Hararge Coffee (Coffeaarabica L). Germplasm for Quantitative Traits 2 (1) 13-18.

[16] Endale T, Taye K, Antenhe N, Tesfaye S, Alemseged Y, Tesfaye A (2008). Research on coffee field management. pp. 187-195. In: Girma A, Bayetta B, Tesfaye S, Endale T, Taye K (eds.). Coffee Diversity and Knowledge. Proceedings of a National Workshop Four Decades of Coffee Research and Development in Ethiopia, 14-17 August 2007, Addis Ababa, Ethiopia.

[17] IPGRI (1996). Description for coffee (Coffea sp. and Psilanthus sp.). International Plant Genetic Resource Institute, Rome.

[18] Singh RK, Chaudhary BD (1985). Biometrical methods in quantitative genetic analysis. Kalyani publishers, New DelhiLudhiana, India's p. 318.

[19] Seyoum Seifu. (2003). Genetic divergence for seedling parameters and associations among agronomic traits in the Ethiopian coffee (C. arabica L.) germplasm. An MSC thesis presented to the school of graduate studies of Haramaya University, Haramaya, Ethiopia. pp. 91.

[20] Ermias Habte (2005). Evaluation of Wellega coffee germplasm for yield, yield components and resistance to coffee berry disease at early bearing stage. M.Sc. Thesis Submitted to Graduate Studies of Haramaya University, Haramaya, Ethiopia. 69 pp.

[21] Olika K, Sentayehu A, Taye K, Weyessa G (2011). Variability of quantitative Traits in Limmu Coffee (Coffea arabica L.) in Ethiopia. International Journal of Agricultural Research 6: 482-493.

[22] Getachew W, Sentayehu A, Taye K, Tadesse B (2013). Genetic Diversity Analysis of Some Ethiopian Specialty Coffee (Coffeaarabica L.) Germplasm Accessions Based on Morphological Traits Time Journals of Agriculture and Veterinary Sciences, 1 (4): 47-54.

[23] Gizachew A, Hussien M, Taye K (2017). Genetic Variability of Sidama Coffee (Coffea Arabica L.) Landrace for Agromorphological Traits at Awada, Southern Ethiopia. Academic Research Journal of Agricultural Science and Research 5 (4): 263-275, DOI: 10.14662/ARJASR2017.025 ISSN: 23607874 http://www.academicresearchjournals.org/ARJASR/Index.htm

[24] Gizachew A, Hussein M (2017)."Agro-Morphological Characterization of Sidama Coffee (Coffea Arabica L.) Germplasm Accession under its Specialty Coffee Growing Area, Awada, Southern Ethiopia", International Journal of Research Studies in Science, Engineering and Technology 4 (12): 11-23. 